\title{
On the Correlative Nature of Hungarian Left-peripheral Relatives
}

\author{
Anikó Lipták \\ ULCL, Leiden
}

\begin{abstract}
This paper takes a close look at the properties of Hungarian relative clauses that occur in the left periphery of the main clause, preceding a (pro)nominal associate. It will be shown that these left-peripheral relative clauses differ in many ways from relative clauses dislocated on the right periphery, as well as from relative clauses embedded under a (pro)nominal head. To capture the precise syntax of these left-peripheral clauses, these will be compared to ordinary left-dislocated items, with which they have some properties in common. Despite the surface similarities between the two, however, there are a few decisive aspects of behaviour, most notably, distributional properties and connectivity effects, which argue against taking left-peripheral relatives as cases of clausal left-dislocates in Hungarian. Instead, one is led to consider these as correlative clauses, on the basis of the properties they share with wellestablished correlatives in languages like Hindi.
\end{abstract}

\section{Introduction}

The investigation of topicalization and left-dislocation of various constituents has played a significant role in devising a syntactic theory about the left periphery of sentences, determining the clausal architecture as well as the discourse roles of certain sentence-initial positions. Recent years have brought renewed interest in the types of left-dislocated elements (Anagnostopoulou et al. 1997), bringing forth a great deal of evidence for fine-grained distinctions between various types of elements that are moved or base-generated in the left periphery, and their relation to the rest of the clause. It is in this context that the study of clause-size material in the left periphery gains importance.

In the present study I examine the left-peripheral distribution of (headless) relative clauses in Hungarian (with comparative evidence from Hindi), in order to establish what mechanism is responsible for their sentence-initial placement and whether this mechanism is similar to what underlies the placement of other left-peripheral topics. After a short introduction to the phenomenon (section 2), it will be shown in section 3 that left peripheral relative clauses are special in that they cannot be derived by movement processes from a lower position. As section 4 will show, their association with a (pro)nominal constituent in the main clause and their left-peripheral position raise the suspicion that these are left-dislocated via ordinary left-dislocation. A 
more in-depth comparison between left-dislocation and the relative placement strategy, however, reveals that the two cannot be fully conflated. Section 5 will reveal that the characterization of left peripheral relative clauses as correlatives is more likely to be on the right track.

The study of the behaviour of left-peripheral relative clauses thus contributes to many fields of enquiry. It provides insights about the syntax of clausal peripheries, and it contributes to our knowledge of the typological variation in relative clause formation as well.

\section{Relative Clauses in the Left Periphery of Hungarian}

The syntax of relative clauses displays a great deal of typological variation across the world's languages and can give rise to different patterns even within one language. In this paper I will be concerned with positional variation in the placement of relative clauses that are dissociated from the nominal phrase they modify. The primary objects of the present study are those relative clauses which do not appear in the regular embedded position following a nominal, but can be found to the left of an associated demonstrative pronominal or a full DP with a demonstrative item, as illustrated in the following examples. ${ }^{1}$ The term I will use for these types of relative clauses is left peripheral relative clauses or LPRCs for short. ${ }^{2}$

(1) [RCAmit Mari tegnap fözött ], azt nem ette meg János. what-ACC Mari yesterday cooked that-ACC not ate PV John

'John did not eat what Mari cooked yesterday.'/ 'As regards the things

Mari cooked yesterday, John did not eat them.'/ 'John didn't eat what Mari cooked yesterday (while he presumably did eat other things).'

\footnotetext{
${ }^{1}$ The glosses in this article correspond to the following: POSS = possessive; POT $=$ potential $($ may $) ; \mathrm{PV}=$ preverb $($ al element $) ; \mathrm{REL}=$ relative morpheme; $\mathrm{RC}=$ relative clause, $\mathrm{ACC}=$ accusative; ERG = ergative. Nominative case is unmarked. Person and number conjugation on verbs is indicated only when relevant.

${ }^{2}$ The existence of relatives with pronominal heads was already acknowledged by Lehmann (1984), who refers to these as free relatives with a pronominal head, and by Smits (1988), who calls them semi-free relatives. Recently, Citko (2004) has used the term light-headed relatives for them. Assimilating these to free relatives is done primarily on the basis of their meaning: they are interpretationally non-distinct from ordinary free relatives like (i):
}

(i) John devours [RC whatever Mary cooks for him].

For ease of exposition, in the present paper I gloss over existing syntactic differences between light-headed relatives (ex. 1) and those with a full DP associate (ex. 2), as I believe the differences are immaterial for the phenomenon to be illustrated in this paper. For an introduction to the two types in Hungarian, see Kenesei 1992, 1994 and for a recent account of the difference between them in Polish, see Citko 2004. 


\section{(2) [RC Amit Mari tegnap fözött], azt a levest what-ACC Mari yesterday cooked that-ACC the soup-ACC nem ette meg János. \\ not ate PV John \\ 'John didn't eat the soup that Mari cooked yesterday.'/ 'As regards the soup Mari cooked yesterday, John didn't eat it.' / 'John didn't eat the soup that Mari cooked yesterday (while he presumably did eat other things).'}

In these examples, the LPRCs (in square brackets) are linked to a demonstrative pronominal or definite noun phrase in the main clause (indicated in bold). The interpretive relationship between the relative and the nominal constituent in (1) or (2) is exactly the same as that found in (3) and (4), where the order of these elements is the reverse and we are not dealing with a LPRC.

(3) János megette azt [ $\mathrm{RC}_{\mathrm{RC}}$ amit Mari tegnap fözött]. János ate that-ACC REL-what-ACC Mari yesterday cooked 'John ate up what Mari cooked yesterday.'

(4) János azt a levest [RC amit Mari tegnap fözött]megette. John that-ACC the soup-ACC REL-what-ACC Mari yesterday cooked ate 'John ate up the soup that Mari cooked yesterday.'

In (3) and (4), the nominal element precedes the relative clause. The bolded elements, just like in (1) and (2), refer to 'the thing/soup Mari cooked yesterday'.

The difference between (1)/(2) and (3)/(4) has to do with discourse functions: in the case of LPRCs, the relative clause can be interpreted as an aboutness topic or a contrastive topic (although such interpretations are not obligatory), while embedded relative clauses do not support such readings at all, as the translations also indicate. The reading in which the relative clause functions as a contrastive topic has a characteristic intonation pattern to which we will return in section 4 below.

A simple-minded account of the positional variation between LPRCs in $(1) /(2)$ and embedded relatives in (3)/(4), with the observed discourse difference, would therefore have it that LPRCs are derived by fronting from an embedded position to a sentence-initial topic or contrastive topic position. A closer look, however, reveals that this is not the case: LPRCs are not related transformationally to embedded relatives. LPRCs are not derived by movement from a lower position: they originate in the high surface position that they occupy in overt syntax. The following section will provide evidence for this claim, with the help of several tests that distinguish LPRCs from embedded relative clauses, establishing that a movement account cannot be applied to LPRCs. 


\section{LPRCs: Base Generation}

I will argue that examples (1)/(2) and (3)/(4) above are not simply word order variants of each other derivable by preposing the relative clause in (1)/(2) from an underlying (3)/(4). LPRCs and embedded relatives are crucially different in their underlying syntax: they constitute two fundamentally different relativizing strategies. In this section, I enumerate five unrelated pieces of evidence that unambiguously prove this claim. These come from the following areas:

(i) the (un)availability of certain (pro)nominal heads/associates in one construction, but not the other (section 3.1);

(ii) differences in number agreement with the pronominal element (section 3.2 );

(iii) a lexical test for the free relative status of LPRCs (section 3.3);

(iv) anti-reconstruction effects exhibited by LPRCs (section 3.4);

(v) the availability of multiple relative clauses in LPRCs (section 3.5).

In the following five sections these phenomena will be discussed one by one.

\section{1 (Pro)nominal Heads/Associates: Definiteness Restrictions}

The first difference between LPRCs and embedded relatives has to do with the kind of nominal constituent they can appear with. While LPRCs can only be followed by (pro)nominals that are definite, embedded ones can be embedded under both definite and indefinite items:

(5) [RCAkivel Mari moziba jár], az /az a fiú illedelmes. REL-who-WITH Mari cinema-TO goes that/that the boy polite

'The boy Mari goes to the cinema with is polite.'

(6) * ${ }_{\mathrm{RC}}$ Akivel Mari moziba jár], egy fiú illedelmes. REL-who-WITH Mari cinema-TO goes aboy polite 'The boy she Mary to the cinema with is polite.'

(7) ${ }_{\mathrm{RC}}$ Akivel Mari moziba jár], mind/*bárki illedelmes. REL-who-WITH Mari cinema-TO goes all/ anyone polite 'Anyone/everyone who Mari goes to the cinema with is polite.'

(8) Az (a fiú) /egy fiú [ ${ }_{\mathrm{RC}}$ akivel Mari moziba jár], illedelmes. that (the) boy/a boy REL-who-WITH Mari cinema-TO goes polite 'A boy/the boy Mary goes to the cinema with is polite.'

(9) Mindenki/bárki [RC akivel Mari moziba jár], illedelmes. everyone/anyone REL-who-WITH Mari cinema-TO goes polite 'Every boy Mari goes to the cinema with is polite.' 
As can be seen from the examples in (5)-(7), LPRCs can be associated only with a definite item (like $a z$ 'that', mind 'all' but not egy fiú 'a boy' or bárki 'anyone'), while embedded relatives (8)-(9) can be associated with indefinite items as well. This split necessitates a different treatment of the two cases, to which we will return in section 5 below.

\subsection{Agreement Patterns}

The second piece of evidence to illustrate the syntactic differences between embedded and LPRCs comes from number agreement phenomena between the relative and the (pro)nominal associate.

The relevant facts can be observed when two conjoined relative clauses with singular relative pronouns appear under one nominal head or are associated with one nominal element. Before illustrating this, it needs to be mentioned that an embedded relative clause with a singular relative pronoun can refer to both singular or plural entities in Hungarian, although the demonstrative head can only be singular:
a. Az [RCaki most jött] bejöhet. that REL-who-SG now arrived-3SG enter-POT-3SG 'The person(s) who just arrived can enter.'
b. *Azok [RCaki most jött] bejöhetnek. those REL-who-SG now arrived-3SG enter-POT-PL 'The person(s) who just arrived can enter.'

The same is true if we have two conjoined relative clauses following the demonstrative element:

(11) Az/*Azok [[RC aki most jött] és [RCaki itt volt]], that/those REL-who now arrived and REL-who here was bejöhet ${ }^{*}$-nek. enter-POT-3SG/*PL

'Those who just arrived and those who have been here already can enter.'

If we turn these constructions into LPRCs, agreement with the demonstrative becomes looser in the second context. While the demonstrative that follows a single singular relative clause has to be singular, as shown in (12), the demonstrative that is associated with conjoined relative clauses can either be singular or plural, as shown in (13):
a. [RCAki most jött] az bejöhet. REL-who-SG now arrived-3SG that enter-POT-3SG
'The person(s) who just arrived can enter.' 


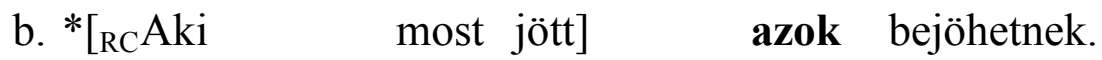 REL-who-SG now arrived-3SG those enter-POT-PL 'The person(s) who just arrived can enter.'

[[RCAki most jött] és [RC aki now arrived and REL-who here was
$\quad$ REL-who now
az/azok bejöhet/-nek.
that/those enter-POT-3SG/PL \\ 'Those who just arrived and those who have been here already can enter.'}

The two varieties of (13), with singular or plural resumptive element, do not differ in meaning: both resumptives are plural in reference. Agreement being the reflection of certain syntactic configurations, we have to conclude that the observed difference in agreement morphology indicates that the structural relationship between the pronominal and the (conjoined) relative clause is different in (11) and (13). ${ }^{3}$

\subsection{Relative Pronoun Selection: The Distribution of amely 'which'}

As has been observed by Kenesei (1992), the distribution of the relative pronoun amely 'REL-which' is crucially different in LPRCs and embedded relatives. Amely 'REL-which', presumably due to its D-linked status, can only occur in relatives with a full nominal head, as the following example in (14) illustrates:

(14) Olvasom *(azt a könyvet) [RC amelyet most vettem] read-1SG that-ACC the book-ACC REL-which-ACC now bought-1SG 'I am reading the book that I have just bought.'

Without the overt head included in brackets, the sentence is ungrammatical, showing that amely 'REL-which' cannot be used in free relative clauses. Linear dissociation from the head, however, does not result in ungrammaticality. Observe (15), where the relative is dissociated from the head via rightward extraposition without leading to ungrammaticality:

\footnotetext{
${ }^{3}$ Note that the agreement pattern that we see in (11)-(13) above is paralleled in the verbal domain as well. Subject-verb agreement with conjoined singular nominals shows the same behaviour, necessitating an explanation that extends beyond considerations of pronominal reference alone:
}

(i) a. Eljöttt/*eljöttek Péter és Mari. came-3sg/came-3pl Péter and Mari

b. Péter és Marieljött/eljöttek.

Péter and Mari came-3sg/came-3pl 'Péter and Mari came.' 
(15) Azt a könyvet olvasom [RC amelyet most vettem]. that-ACC the book-ACC read-1SG REL-which-ACC now bought-1SG 'I am reading the book that I have just bought.'

Interestingly, however, if the relative clause is to the left of the nominal item, we get an ungrammatical result:

(16) $*$ [RC Amelyet most vettem $]$ azt a könyvet olvasom. REL-which-ACC now bought-1SG that-ACC the book-ACC read-1SG

From the contrasts between (14) and (15), we can observe that when a relative clause appears in a left-peripheral position preceding its apparent associate 'head', it behaves as a free relative clause. In other words, it is not headed and does not originate from an underlying position where it was headed at some point in the derivation. This explains straightforwardly why amely is excluded from left-peripheral relatives: it cannot occur there because these relative clauses are not headed by any nominal. That is, the main clause nominal azt a könyvet 'that book' does not serve as a head for the relative clause in these examples, while it undoubtedly does serve as a head in (14) and (15). The link between the relative on the left and the main clause nominal is not a headdependent relation. Due to this, I will from now on refer to the main clause (pro)nominal as a 'resumptive element' and in section 5, as a 'correlate'.

\subsection{Connectivity Effects: No Reconstruction}

Another very robust argument to the effect that LPRCs in (1)/(2) are basegenerated in the left periphery without the corresponding nominal associate as their head comes from anti-reconstruction facts. Checking the licensing conditions of R-expressions in the relative clause, we can see that LPRCs do not reconstruct. Observe (17), where an R-expression is contained the LPRC. It can freely be coindexed with the subject of the main clause:

$$
\begin{aligned}
& \text { [RC Akit Szeret Mari } \mathrm{i}_{1} \text {, azt meghívta } \text { pro }_{\mathrm{i}} \text { a buliba. } \\
& R E L-\text { who-ACC loves Mari that-ACC invited } \\
& \text { 'Who(ever) Mari loves, she invited to the party.' }
\end{aligned}
$$

If the relative clause did reconstruct back into the object position, we would expect that coindexation between the pro subject of the main clause and the Rexpression Mari 'Mari' in the relative would be impossible. Coindexation, however, is possible, arguing against reconstruction. Embedded or rightextraposed relatives cannot be construed with coreference between the pronominal subject of the main clause and the R-expression, due to the fact that the former c-commands the latter: 
(18) a. *Meghívta pro $_{\mathrm{i}}$ azt $\quad\left[\mathrm{RC}\right.$ akit szeret Mari $\left._{\mathrm{i}}\right]$ a buliba. invited that-ACC REL-who-ACC loves Mari the party-TO

'Who(ever) Mari loves, she invited to the party.'

b. *Meghívta pro $_{\mathrm{i}}$ azt a buliba [RC akit szeret Mari $\mathrm{i}_{\mathrm{i}}$ ] invited that-ACC the party-TO REL-who-ACCloves Mari

'Who(ever) Mari loves, she invited to the party.'

Note also that the behaviour of (17) is not due to some kind of linearity effect. An R-expression inside an object DP cannot be coindexed with the subject pronoun in Hungarian, even when the former is left-peripheral and thus precedes the latter:

(19)*Az Annáról $l_{\mathrm{i}}$ írt könyvet nem olvasta pro ${ }_{\mathrm{i}}$ még. the Anna-ABOUT written book-ACC not read-3SG yet 'She did not read the book about Anna yet.'

If reconstruction effects can be taken to be diagnostics for movement (Fox 2000), these facts argue against a movement scenario for the placement of LPRCs. Unlike embedded and right-extraposed object relatives in (18), the LPRC in (17) does not originate in a clause-internal position c-commanded by the matrix subject. This corroborates the finding of section 3.3 above: LPRCs are not derived by movement. We will return to these facts in more detail in section 4 below.

\subsection{Multiple Relatives}

The last piece of evidence to the effect that LPRCs are special in the way described above comes from the distribution of multiple relatives. Multiple relatives are relative clauses with more than one relative pronominal, referring to more than one entity, as the following example illustrates:
(20) ${ }_{\mathrm{RC}} \mathrm{Aki}$ amit
kér ], az azt
elveheti.
REL-who REL-what-ACC wants that that-ACC take-POT-3SG

'Everyone can take what he/she wants.'

The main clause pronominals $a z$ 'that' and $a z t$ 'that-ACC' refer back to the individuals picked out by the relative clause.

The multiple relative construction is a well-attested sentence-type in Hungarian (Lipták 2000). Such sentences cannot be transformationally derived from an underlying headed structure, due to the fact that the relative clause, obviously one constituent, would have to be extracted from under two heads at the same time (both $a z$ 'that' and azt 'that-ACC'). These sentences therefore are prima facie evidence for the claim that the LPRC hosts a base-generated free relative clause that has no syntactic head.

It is also noteworthy that multiple relatives are restricted exclusively to the left-peripheral position. They are excluded from any clause-medial or right- 
extraposed position, which suggests that the latter are positions where they would have to be construed as headed:

\begin{tabular}{|c|c|c|c|}
\hline $\begin{array}{l}(21)^{*} \mathbf{A z} \text { azt } \\
\text { that that }-A C C\end{array}$ & $\begin{array}{l}\text { amit } \\
R E L-w h a t-A C C\end{array}$ & $\begin{array}{l}\text { kér ] } \\
\text { wants }\end{array}$ & $\begin{array}{l}\text { eti. } \\
\text { POT-3SG }\end{array}$ \\
\hline $\begin{array}{l}(22) * \mathrm{Az} \text { azt } \\
\text { that that }-A C C\end{array}$ & 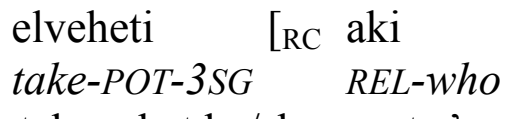 & $\begin{array}{l}\text { amit } \\
\text { REL-what-ACC }\end{array}$ & $\begin{array}{l}\text { kér ]. } \\
\text { wants }\end{array}$ \\
\hline
\end{tabular}

These facts deliver the same results as the empirical evidence in section 3.4 above: LPRCs are not derived by movement.

\subsection{Interim Summary}

The data presented in the preceding five sections leave little room for doubt that the behaviour of LPRCs is fundamentally distinct from that of relatives clauses that occur in embedded positions following their nominals. It is therefore safe to conclude on the basis of the evidence presented above that the linear placement of the relative clause with respect to its nominal associate can result in two different construction types, which are not related. LPRCs are base-generated free relative clauses, while those following their (pro)nominal associate (both in adjacent and non-adjacent positions) are headed relatives. Left periphery placement of a relative clause is a basegeneration strategy, which is, as I will argue in section 5, a substrategy of relative clause formation. Schematically, the constructions then conform to the following structural patterns:

$$
\begin{aligned}
& \text { (23) a. } \left.\left[\begin{array}{ll}
R C & \ldots .
\end{array}\right]\left[\begin{array}{lll}
\ldots & \text { DEM/DP } & \ldots
\end{array}\right]\right] \text { LPRCs } \\
& \text { b. }\left[\begin{array}{lll}
\ldots & \mathbf{D E M} / \mathbf{D P} / \mathbf{N P}\left[\begin{array}{ll}
R C & \ldots .
\end{array}\right]
\end{array}\right] \text { headed relatives }
\end{aligned}
$$

Hungarian relative clauses to the left of a (pro)nominal associate (LPRCs) are base-generated in their surface position as free relative clauses and are not linked to any embedded position clause-internally.

The remainder of this article will focus on LPRCs exclusively. In the next two sections, I will further specify the precise relation of these relatives to the rest of the clause. Section 4 will introduce and eliminate the possibility of generating LPRCs as left-dislocated constituents, and section 5 will argue for relating them to correlatives.

\section{A Likely Suspect: Left Dislocation}

As already mentioned in the introductory section (section 2) above, LPRCs can have the discourse interpretation of aboutness topics or contrastive topics. Both types of topics being left-peripheral constituents in Hungarian, it seems 
natural to conceive of these LPRCs as referential, free relative DPs occupying topic positions. In this section I will consider whether analyzing these relatives as left dislocated items is indeed a viable option. The ultimate conclusion will be negative: LPRCs are not to be conflated with left dislocation (or any other topic type) in Hungarian. This conclusion will be arrived at after comparing left-dislocated elements (introduced briefly in section 4.1) to left-peripheral relatives in sections 4.2 and 4.3. As these sections will show, the differences greatly outnumber the similarities between the two construction types.

\subsection{Left Dislocation in Hungarian}

Hungarian has several types of topics, which can be differentiated according to semantic, syntactic and intonational properties. The three main syntactic types are: ordinary topics, left dislocates and contrastive topics. Ordinary topics function as logical subjects of predication (É. Kiss 1987), and they occupy specifier positions in TopP (an iterable functional projection). Left dislocates are overwhelmingly contrastive items; they occupy a unique position in the left periphery, and they are linked to a resumptive element. Contrastive topics are necessarily contrastive items that also occupy a unique position (in complementary distribution with left dislocates), and which do not associate with resumptive elements (Gécseg 2001; Lipták 2001).

Of these three types, the type that is relevant for the analysis of LPRCs is the one involving left dislocation, as this is the only type of topic that, similarly to left-peripheral relatives clauses, combines with a resumptive element following it and with which it is coreferential. The resumptive element used in left dislocation is the distal demonstrative pronoun az 'that', which agrees in case with the left dislocated constituent. Some speakers can also use the personal pronoun $o$ ' 'he/she' as the resumptive, but this element is losing ground to $a z$ 'that' in present-day Hungarian:
(24) Tegnap Péter
(az) AJÁNDÉKOT kapott Maritól.
yesterday Péter
that present-ACC got
Mari-FROM
'Péter, he got A PRESENT from Mari yesterday (while other people might have got something else.)'

Left-dislocated elements, which imply contrast in a way that is indicated in the translation above, are characteristically pronounced in Hungarian with a rising intonation (marked by $\sqrt{ }$ in the following examples) followed by a slight pause.

As (24) illustrates, the left-dislocated noun phrase Péter 'Péter' can be preceded by normal topics (tegnap 'yesterday') and is necessarily followed by an operator, like contrastive focus (ajándékot 'present-ACC'). As the next section will illustrate, left dislocation is not a root phenomenon in Hungarian, but can be freely embedded in any kind of that-clause. 
Next to the clearly contrastive and phonologically distinct pattern of left dislocation, there are contexts, characterizing spontaneous, oral discourse, in which structures like (24) occur without an obvious contrastive reading, without the accompanying characteristic intonation and without an obligatory operator item in the clause, as illustrated in (25). In these contexts, the noncontrastive left-dislocated phrase is used to mark a new information unit, ${ }^{4}$ much as ordinary topics are:

(25) Erre Péter, (az) fogta magát és elszaladt. then Péter that took himself-ACC and away.run 'Then Péter, he got up and ran away.'

Structurally, the left dislocated element can be taken to occupy the specifier of a special functional projection $(L D P)$. Recall from (24) above that these elements are preceded by ordinary topics and followed by quantificational items and focus, suggesting that LDP is lower than TopP but higher than the QP projection in Hungarian. On the simplest assumption, the left-dislocated phrase and the resumptive element stand in apposition and form one constituent (É. Kiss 1987):

(26) $[\mathrm{CP}[\mathrm{TopP*}$ [LDP $[\mathrm{XP}(\mathrm{az})][\mathrm{LD}[\mathrm{QP} *$ [FocP $([\mathrm{VP} \cdots])]]]]]]$

For some further properties of left dislocation, see also the next two sections.

\subsection{LPRCs and Dislocated Phrases: Similarities}

LPCRs and left-dislocated elements in Hungarian show similarities in more than one domain. They show parallels when it comes to (i) their meaning, (ii) the choice of their resumptive element and (iii) their position in the clause.

(i) Interpretation. As was already indicated in section 2 above in the example repeated here in (27), LPRCs can be interpreted as topics. Apart from the 'neutral interpretation' exemplified in (27a), where the relative clause marks new information, the relative clause can be understood as an aboutness topic, as in (27b), and as a contrastive topic, as in (27c):

(27) [RC Amit Mari tegnap fözött ], azt nem ette meg János. what-ACC Mari yesterday cooked that-ACC not ate PV John

a. 'John did not eat what Mari cooked yesterday.'

\footnotetext{
${ }^{4}$ Prince (1998) refers to this type of left dislocation in English as 'simplifying left dislocation', because it serves to simplify the discourse processing of discourse-new entities. As she argues, removing discourse-new entities from a sentence-internal position and placing them in a dislocated position on the left periphery creates a separate discourse unit for them, which simplifies processing.
} 
b. 'As regards the things Mari cooked yesterday, John did not eat them.'

c. 'John didn't eat what Mari cooked yesterday (while he presumably did eat other things).'

The intonational properties characterizing each interpretation are not the same in the three cases. The contrastive reading of $(27 \mathrm{c})$ corresponds to the intonation pattern associated with contrastive left dislocation (ex. 24) above that is, it involves a rising pitch and secondary stress on the relative clause, followed by a slight pause. Interpretations (27a) and (27b) do not have such an intonation pattern; in these cases both the relative and the main clause are pronounced with neutral intonation. Interpretation and intonation thus suggest a parallel between the relative construction in (27c) and the sentence in (24), which is an instance of contrastive left dislocation. $(27 \mathrm{a}) /(27 \mathrm{~b})$ can be thought of as parallel to (25), an instance of non-contrastive left dislocation.

(ii) Resumptive element. As was already illustrated above, relative clauses on the left periphery can use a resumptive pronominal that is the same as that of left dislocates: the distal demonstrative pronoun.

(iii) Embeddability and uniqueness. The exact position of left dislocates and LPRCs shows some parallels as well. Apart from being left-peripheral, both can be freely embedded in a that-clause, as shown in (28a) and (29a), and neither can be embedded in a relative clause, as shown in (28b) and (29b):

(28) a. Azt mondják, hogy $\sqrt{ }$ János, az AJÁNDÉKOT kapott. that say-3PL that János that present-ACC got 'They say that János, he got a PRESENT.'
b.??a lánytól, akitől
JJános, az AJÁNDÉKOT kapott that girl-ABL REL-who-FROM János that present-ACC got 'the girl, from whom, János, he got a PRESENT.'

(29) a. Azt mondják, hogy [aki eljön], az ajándékot kapott. that say-3PL that REL-who comes that present-ACC gets 'They say that the person who comes, he got a present.'
b.??a lánytól, akitől
[aki eljön] az ajándékot kap that girl-ABL REL-who-FROM REL-who comes that present-ACC gets 'The girl, from whom, the person who comes, he got a present.'

Both left dislocates and LPRCs may occur only once per clause:
a. * $\sqrt{ }$ Maritól $\sqrt{ }$ Péter attól
az nem kapott ajándékot. Mari-FROM Péter that-FROM that not got present-ACC
'As for Péter, as for Mari, he did not get a present from her.' 
b. *[RC Aki eljön], [RC amikor megérkezik], az akkor telefonáljon. REL-who comes REL-when arrives that then call-IMP 'The person who comes, and when he arrives, should call at that time.'

These observations suggest that the syntax of LPRCs runs at least partly parallel to that of left dislocation, so that an initial hypothesis about LPRCs might be that they have the syntax of left-dislocated nominals. Those that occur with demonstrative pronouns as resumptives can thus be assigned the following structure:

$$
\text { (31) }\left[\mathrm{CP}\left[{ }_{\mathrm{TopP}} *[\mathrm{LDP}[D P R E L-w h \ldots](\mathbf{a z})][\mathrm{LD}[\mathrm{QP} * \quad[\mathrm{FocP}[\mathrm{NegP}([\mathrm{VP} \ldots])]]]]\right]\right.
$$

Further scrutiny, however, reveals that this picture is too simplistic: the structure of LPRCs is not that in (31). Apart from the obvious similarities mentioned in this section, there are a number of dissimilarities that argue against a parallel treatment of left-dislocated items and LPRCs. The next section illustrates these.

\subsection{LPRCs and Dislocated Phrases: Differences}

Differences between left-peripheral relatives and left-dislocated items can be found in their precise syntactic placement, the distribution of resumptive elements, focusing possibilities and reconstruction effects. In what follows these properties will be illustrated in detail.

(i) Placement in the clause. As was shown in example (24), left dislocates can comfortably follow other, ordinary topics in the Hungarian clause. In contrast, LPRCs occur acceptably only in sentence-initial and cannot be preceded by any constituent without a considerable degradation in their acceptability:

(32)??A szervezőktöl [RC aki eljön] az ajándékot kapott. the organizers-FROM REL-who comes that present-ACC gets 'Who(ever) comes gets a present from the organizers.'

(ii) Optionality of the resumptive element. The nature of the resumptive element also seems to be different in the two cases. First, note that LPRCs can choose from a larger set of resumptive items: either demonstrative pronominals or full DP nominals containing demonstrative forms (see ex. (1) and (2) above), while left dislocates can only have pronominal resumptives:

$$
\begin{aligned}
& \text { (33)* } \text { *éter az a fiú AJÁNDÉKOT kapott Maritól. } \\
& \text { Péter that the boy present-ACC got Mari-FROM } \\
& \text { 'Péter, he got A PRESENT from Mari.' }
\end{aligned}
$$

Furthermore, even if one puts full DP resumptives aside for a moment, there are also many striking differences between the pronominal resumptive element 
we find with relatives and those with left dislocates. First of all, the resumptive element is optional with left dislocates (in both their neutral and contrastive meanings), but obligatory with relative clauses. This property of left dislocation is illustrated in (34), where rising intonation clearly marks Péter as a left dislocate. Relative clauses are illustrated in (35). This example shows that the resumptive can only be absent if it bears nominative or accusative case.

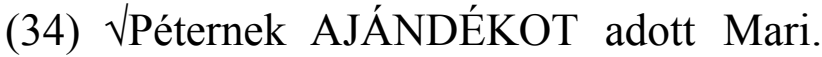
Péter-DAT present-ACC gave Mari

'To Péter, Mari gave a PRESENT.'

(35) a. [RC Amit Mari tegnap fözött ], (azt) János megette. REL-what-ACC Mari yesterday cooked that-ACC John ate 'John ate up what Mari cooked yesterday.'

b. [RC Akit bemutattál ], *(annak) köszöntem. REL-what-ACC introduced-2SG that-DAT greeted-1SG 'I greeted the person you introduced to me.'

(iii) Adjacency of the resumptive element. The structural conditions on the placement of the resumptive item differ in the two cases. The resumptive element is always adjacent to left-dislocates, as in (36), but is much freer in the case of relatives, as in (37), where ordinary topics can precede it: ${ }^{5}$
(36)*Tegnap $\sqrt{ }$ Péter Maritól
az AJÁNDÉKOT kapott. yesterday Péter Mari-FROM that present-ACC got 'Péter, he got A PRESENT from Mari yesterday (while other people might have got something else.)'
(37)?[Aki eljött], Maritól az ajándékot kapott. REL-who came Mari-FROM that present-ACC got 'The people who came got a present from Mari.'

(iv) Discourse functions. The resumptive element of relative clauses shows a greater flexibility not only when it comes to its positions but also in its discourse functions. In case the relative clause has non-contrastive intonation $(27 \mathrm{a}, \mathrm{b})$, it is possible for the resumptive to appear as the focus of the sentence, as can be seen in (39). The same is never possible with left dislocates (38):

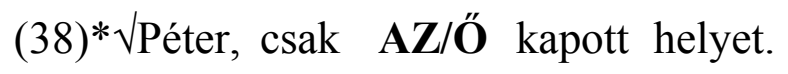

Péter only that/he got place-ACC

\footnotetext{
${ }^{5}$ Non-adjacency between the relative clause and the resumptive pronoun is less preferred to full adjacency, but nevertheless does not result in full ungrammaticality, unlike in the case of left dislocation.
} 
(39) [Aki fizetett], csak $\mathbf{A Z}$ kapott helyet. REL-who paid only that got place-ACC 'Only those who paid got a place.'

The ungrammaticality of (38) is due to the fact that the left dislocated constituent and its resumptive pronoun are not only co-referring, but also identical in their feature content as a result of the complex appositive structure they form (cf. 26 above). Since the left-dislocated element is marked for a very specific discourse function, that of a contrastive topic, the resumptive cannot assume any other discourse function either, or else this would result in an interpretive clash. The same does not hold true of LPRCs. (39) is a grammatical sentence with focus on the relative clause. This suggests, together with the evidence from the various interpretive possibilities in (1), (2), and (27) above that LPRCs are not restricted to a specific discourse role. Depending on the position their resumptive element occupies, they can be topics, contrastive topics or even foci. If they were to originate in a specific position reserved for left dislocates only, this flexibility in interpretation would be impossible to account for.

(v) Reconstruction effects. Last but not least, one finds crucial differences between LPRCs and left dislocates when it comes to their locus of interpretation, i.e. in the domain of reconstruction effects. It was already illustrated in section 3.4 above that relative clauses on the left periphery are not reconstructed to any lower position. Left-dislocates, in contrast, show obligatory reconstruction, which is illustrated here by Binding Principle A effects (40), Binding Principle C effects (41) and bound pronoun readings (42).

(40) Egymás könyveit, azt GYAKRAN olvassák a fiúk. each.otherbook-POSS.3SG-PL-ACC that-ACC often read-3PL the boys 'Each other's books, the boys OFTEN read those.'

(41)*Alex ${ }_{i}$ könyvét, azt nem pro olvassa. Alex book-POSS.3SG-ACC that-ACC not reads

'Alex's book, he (=Alex) does not read.'

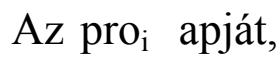
azt
mindenki $i_{i}$ szereti.
the father-POSS.3SG-ACC that-ACC everyone loves
'Everyone loves his father.'

These examples unambiguously show that at the level where binding relations are computed, the left-dislocated item does not occupy the left-peripheral position in which it surfaces in overt syntax. It has to be reconstructed to a lower position. This is in sharp contrast to the behaviour of LPRCs, which, as in (17) repeated here, do not show reconstruction effects (regardless of which intonation pattern is used with them): 
(17)
$[\mathrm{RC}$ Akit
szeret Mari $\mathrm{i}_{\mathrm{i}}$, azt
meghívta pro $_{i}$ a buliba.
REL-who-ACC loves Mari that-ACC invited
the party-TO
'Who(ever) Mari loves, she invited to the party.'

The stark contrast between (40)-(42), on the one hand, and (17), on the other, provides another piece of evidence against treating LPRCs as ordinary left-dislocated elements.

Before going on, note in passing that the behaviour of LPRCs in many respects parallels another type of topic construction, hanging topic left dislocation (HTLD) in languages that have this strategy. HTLD, a frequent dislocation strategy in Germanic languages, is a dislocation pattern that has resumptive pronouns in low positions and involves no case matching between these and the dislocated item. It is interesting to note that just like Hungarian LPRCs, hanging topics show no connectivity effects (Grohmann 2000):

(43) [Die Tatsache, dass Alex $_{\mathrm{i}}$ arm ist $]_{\mathrm{j}}, \mathrm{er}_{\mathrm{i}}$ misst $_{\mathrm{ihr}} \mathrm{j}_{\mathrm{j}}$ keine Bedeutung bei. the fact that Alex poor is he attaches that-DAT no importance to 'The fact that Alex is poor, he doesn't attach importance to it.'

Next to connectivity effects, LPRCs and hanging topics share the common property that they can occur together with other topic constituents. The two are different, however, in two crucial properties: the fact that there can be more HTLDed items per clause, while relatives are unique; and the fact that HTLD is a strictly root phenomenon. ${ }^{6}$ This clearly argues against taking Hungarian LPRCs as HTLD constructions. LPRCs in Hungarian are 'hanging' items only to the extent that they do not reconstruct, but crucially lack the extra-sentential nature of hanging topics.

In this section it was shown that LPRCs differ from left-dislocated element in the following: (i) LPRCs, but not left dislocates, need to be clause-initial constituents; (ii) the resumptive element is optional with left dislocates but not with relatives; (iii) the resumptive element needs to be adjacent to the left dislocate but can be non-adjacent to the LPRC; (iv) the resumptive element can assume the logical function of focus only in the case of relatives; and (e) reconstruction effects characterize left dislocation only.

\footnotetext{
${ }^{6}$ Contrastive left dislocation in German can be embedded, although under bridge verbs only (which allow for V2 in their complement clause) (Grohmann 2000):
}

(i) Ich glaube, diesen Satz, den haben wir nun allesatt. I believe this sentence-ACC that-ACC have we now all enough 'I believe this sentence, we've had enough of by now.'

HTLD, on the other hand, cannot be embedded even under bridge verbs:

(ii) *Ich glaube, dieser Satz, wir haben ihn nun alle satt. I believe this sentence-NOM we have he-ACC now all enough 'I believe this sentence-ACC, we've had enough of it by now.' 


\subsection{Interim Summary}

The previous two sections provided a descriptive account of the behaviour of LPRCs and left dislocated-elements in Hungarian. They showed that apart from some parallelisms, the two constructions differ in a number of properties. The findings are summarized in the following table:

Table 1. Properties of left-dislocated constituents and LPRCs

\begin{tabular}{|c|c|c|c|}
\hline \multicolumn{2}{|l|}{ Properties } & Left Dislocates & LPRCs \\
\hline \multicolumn{2}{|c|}{ topic interpretation } & obligatory & possible \\
\hline \multirow{4}{*}{$\begin{array}{l}\text { resumptive } \\
\text { element }\end{array}$} & type & demonstrative & demonstrative, full DP \\
\hline & obligatoriness & $*$ & $\checkmark($ exc. NOM/ACC $)$ \\
\hline & adjacency to item & $\checkmark$ & optional \\
\hline & focusable & $*$ & $\checkmark$ \\
\hline \multicolumn{2}{|c|}{ obligatory clause-initial position } & $*$ & $\checkmark$ \\
\hline \multicolumn{2}{|c|}{ embeddability } & $\checkmark$ & $\checkmark$ \\
\hline \multicolumn{2}{|c|}{ max. 1 per clause } & $\checkmark$ & $\checkmark$ \\
\hline \multicolumn{2}{|c|}{ obligatory reconstruction } & $\checkmark$ & $*$ \\
\hline
\end{tabular}

As can be seen from the table, both left dislocates and LPRCs can be embedded and can occupy a unique position in the left periphery. Both of them can be associated with a resumptive element, which can appear as a demonstrative pronominal. The resumptive element is optional in the case of left dislocates and obligatory with relatives. The relationship of the resumptive to its 'host' is tighter in the case of left dislocates: they have to be adjacent, unlike the resumptives of LPRCs. Also, the resumptive of left dislocates cannot assume any position corresponding to other logical functions, like that of focus for example, while this is possible with relative clauses. Positionwise, left dislocates seem to occupy a lower position than LPRCs: the latter have to be initial constituents in their clause, while left dislocates can freely be preceded by other topics. Unlike LPRCs, which do not reconstruct, leftdislocated elements necessarily do.

To account for the positional differences one has to assume that although both types of left-peripheral elements occupy a unique position in the left periphery, this position is not the same. ${ }^{7}$ As can be seen from the distribution

\footnotetext{
${ }^{7}$ That they cannot occupy one and the same position is also shown by the fact that it is possible to have both of them in one clause:
} 
of other topics in these constructions, relative clauses are higher than topic constituents, while left dislocates are lower. That is to say, while the structure of left dislocation is that in (26), repeated from above, the structure of leftperipheral relatives has to run along the lines of (44):

(26) Left dislocation

$$
\left[\mathrm{CP}\left[\operatorname{TopP}^{*}(\mathrm{YP})\left[\mathrm{LDP}[X P(\mathbf{a z})]_{\mathrm{i}}\left[\mathrm{LD}\left[\mathrm{QP} *\left[\mathrm{FocP}\left(\left[\mathrm{VP} \ldots \mathrm{t}_{\mathrm{i}} \ldots\right]\right)\right]\right]\right]\right]\right]\right.
$$

(44) $L P R C s$

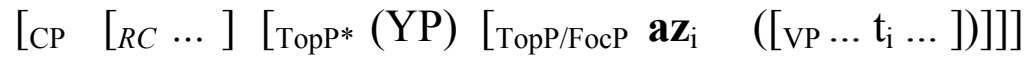

The necessary clause-initial placement of the relative clause points to the fact that it either occupies a specific functional projection atop other topic projections or is adjoined to the highest projection of the clause under the finite complementizer. The following section will elaborate on the nature of this position.

The relationship between the relative clause and the resumptive item is also crucially different from that found in left dislocation. While in the latter the resumptive is an optional element, in the former it is obligatory, indicating that presumably it itself occupies an argument (or adjunct) position in the main clause. This structural disparity can explain the observed differences in reconstruction as well. Left-dislocated elements arguably get into their surface position via movement (together with the demonstrative resumptive pronoun), while LPRCs are base-generated in their clause initial position and are interpreted there. The only element that moves in this construction is the resumptive element, a fully referential item generated in a VP-internal position.

\section{LPRCs as Correlatives}

The previous section provided a detailed comparison between left dislocated elements and LPRCs in Hungarian and showed that the two, although they share some properties, do not have the same underlying syntax. This finding brings up the natural question: if left-peripheral relatives are not dislocated via usual means, why do they occur in the left periphery? The present section deals with this question and argues that LPRCs in Hungarian instantiate a relativization strategy, called correlativization, that is typologically distinct

(i) ?[Aki most jött be], azt $\quad \sqrt{ }$ Péter (az) nem üdvözölte. REL-who now came in that-ACC Péter that not greeted 'Péter, he did not greet the person who entered now (while other people presumably did).'

Sentences like (i) are somewhat unusual due to the high concentration of material in the left periphery. 
from adnominal ones. The placement of these relatives in the left periphery is a characteristic of this relativization strategy.

\subsection{Correlatives: An Introduction}

Correlative constructions involve a relative clause to the left of a main clause containing a pronominal that refers to the entity denoted by the correlative clause. A correlative construction has the schematic structure in (44):

$$
\left[\text { matrix CP }[\mathrm{RC}]_{\mathrm{i}}\left[\text { matrix } \mathrm{CPDEM}_{\mathrm{i}} \ldots\right]\right]
$$

Correlatives thus differ from headed relative constructions, where the relative clause follows the nominal item it modifies. Compare the following two examples from Hindi, which has both the headed (46) and the correlative relativization strategy (47) (Srivastav 1991):

(46) vo laRkii [RC jo khaRii hai] shaayad lambii hai that girl REL standing is maybe tall is

'The girl who is standing may be tall.'

(47) [RC jo laRkii khaRii hai] shaayad vo lambii hai REL girl standing is maybe that tall is

'Every girl who is standing may be tall.'/'The girl who is standing may be tall.'

(46) contains the relative clause in its standard position, following the noun it modifies (vo laRkii 'that girl'), just as in English. (47), on the other hand, has the relative clause on the left, crucially preceding the whole main clause, including the pronominal it modifies (the demonstrative vo 'that'). The latter pattern is called a correlative, because the relative clause is referred to by the vo pronominal element in the main clause.

Correlativization is a typologically relevant notion: some languages make extensive use of the correlative strategy for relativization and other subordinated clausal adjuncts (conditionals, temporals, comparative and degree clauses). Languages in the Indo-Aryan family (Hindi, Bengali, Kashmiri, Oriya) exhibit correlative patterns beyond the relativization structures in (47). Besides the particularity of their placement on the left, correlatives have the following syntactic properties (Bhatt 2003; Dasgupta 1980; Dayal 1996; Izvorski 1996; Sahoo \& Hellan 1998; Srivastav 1991; Wali \& Koul 1997): 
(48) PROPERTIES OF CORRELATIVES:

(i) The correlative clause behaves both internally and externally as a free relative clause, i.e. it does not modify an external head. ${ }^{8}$

(ii) The correlative clause is matched with a so-called correlative pronominal (a demonstrative) in the main clause, with which it entertains a non-local relationship.

(iii)Correlatives (just like free relatives in general; Jacobson 1995) refer to a unique/maximal individual that has the property denoted by the relative clause; due to this property, their matrix correlate can only be a definite element.

(iv) The correlative clause can optionally contain multiple instances of relative pronouns, to be matched with multiple correlative pronominals in the main clause.

As the next section will show, all these properties manifest themselves in the case of left-peripheral relatives in Hungarian as well, providing evidence for the correlative status of these Hungarian constructions.

\subsection{Hungarian LPRCs as Correlatives}

A quick run-through of the properties listed in the previous section immediately shows that Hungarian left-peripheral relatives behave for all intents and purposes like correlatives:

(i) Hungarian LPRCs behave both internally and externally as free relatives, as was shown in section 3.3 above.

(ii) The LPRC is matched with either a demonstrative element or a full DP containing a demonstrative; see examples (1) and (2) above.

(iii) The denotation of LPRCs complies with uniqueness/maximality:

(49) [RC Amit Mari tegnap fözött ], azt János megette. what-ACC Mari yesterday cooked that-ACC John ate

'John ate everything Mari cooked yesterday.'/'John ate the thing Mari cooked yesterday.'

In a situation in which Mari cooked more than one dish, the relative clause in (49) refers to the totality of these; and in a situation in which she only cooked one, (49) refers to this single dish. Also, just as in Hindi correlatives, the

\footnotetext{
${ }^{8}$ This distinction between free and headed relatives becomes less straightforward with the renewed promotion analysis of adnominal relativization (Kayne 1994, following Vergnaud 1974), in which the external head originates inside the relative clause and undergoes displacement.
} 
matrix correlate can only be a definite element in the case of Hungarian as well (the Hungarian (6) is repeated from section 3.1 above, and (50) is taken from Srivastav 1991):

(6) *[RC Akivel moziba jár], egy fiú illedelmes. REL-who-WITh cinema-TO goes a boy-ACC polite

'The boy she goes to the cinema with, is polite.'

(50)*[jo laRkiyãã khaRii hãi] do lambii hãi

REL girls standingare two tall are

'Two girls who are standing are tall.'

(iv) Left-peripheral relatives can contain multiple relative pronouns. (example 20, repeated from section 3.5 above), just like the Hindi (51):

[RC Aki amit kér], az azt elveheti.

REL-who REL-what-ACC wants that that-ACC take-POT-3SG

'Everyone can take what he/she wants.'

(51) [RC jis laRkiine jis laRkeko dekhaa]usne usko passand kiyaa REL girl-ERG REL boy-ACC Saw DEM-ERG DEM-ACC likes

'Which girls saw which boy, she liked him.'

According to the properties (i)-(iv), Hungarian left-peripheral relatives square with Hindi correlatives in all these aspects. This points to the inevitable conclusion: LPRCs in Hungarian and the demonstrative correlate in the matrix substantiate a correlative relation, characteristic of correlative constructions.

The primary conclusion of the discussion here and in section 3 then can thus be summed up in the following. LPRCs are base-generated free relatives in Hungarian, not transformationally related to any nominal that serves as a syntactic head. Instead of being adnominal, they are ad-sentential: they do not originate from a DP-adjoined position. Their interpretative properties (uniqueness/maximality) as well as their association to a demonstrative element in the matrix unambiguously identify them as correlative clauses. The precise nature of the relation between the relative and the demonstrative correlate will be the subject of discussion in the next section.

\subsection{The Fine Syntax of Hungarian Correlatives}

After establishing that Hungarian has a correlative strategy in which a LPRC takes part in a non-local strategy of relativization, this section turns to a more detailed syntactic analysis of this strategy, focussing on the relation between the relative clause and the correlated pronominal. This relationship strongly bears on the question how the right interpretation of correlatives is arrived at. Since the correlative clause makes reference to the same entity that the 
correlate denotes, the correlation between the two has to be established in both syntax and semantics.

As far as Hindi is concerned, there are two, partially opposing views of the relation between the relative clause and its associate. According to Srivastav (1991) and Dayal (1996), the correlative clause modifies the matrix clause as a whole, unlike adnominal relatives which modify a nominal constituent. In syntactic terms this is reflected in the fact that the relative clause is adjoined to IP and acts as a quantificational item binding the demonstrative correlates, which are variables. The primary relation that correlatives involve is thus variable binding.

The more recent account of Bhatt (2003) revisits the facts and provides arguments against the IP-adjunction approach for simple correlatives (those without multiple relative pronominals). On this approach, simple correlatives are base-generated in an adjoined position to the obligatory demonstrative correlative (with which they form a [RC ]-DEM complex), and optionally move to an IP-adjoined position via scrambling. Multiple relatives are basegenerated, just as in Srivastav's account, adjoined to IP, and modify the whole matrix clause. The structural representations of the two construction types are shown in (52) and (53):

(52) $\left[\quad \operatorname{IP}\left[\mathrm{RC} \ldots \mathrm{REL}-\mathrm{XP}_{\mathrm{i}} \ldots\right]_{\mathrm{i}}\left[\mathrm{IP} \ldots\left[t_{\mathrm{i}} \mathrm{DEM}-\mathrm{XP}_{\mathrm{i}}\right] \ldots\right]\right]$

(53) $\left[\quad\right.$ IP $\left[R C \text {...REL-XP } P_{i} \text { REL-XP } P_{j} \ldots\right]_{i, j}\left[I P \ldots\left[D E M-X P_{i} \ldots D E M-X P_{j} \ldots\right] \ldots\right]$

Primary evidence for adjoining the correlative to the demonstrative in the case of simple relatives comes from constructions like (54), which show that the correlative and its correlate can surface together:

(54) Ram-ne [jo laŗkaa tumhaare pi:chhe hai ] us laṛke-ko

Ram-ERG REL boy your behind is DEM boy-DAT

[jo kita:b Shantiniketan-ne chhaapii thii] vo kitaab dii

REL book Shantiniketan-ERG print-pfv was DEM book give-pfv

'Ram gave the book that Shantiniketan had published to the boy behind you.'

In (54), we find two correlative clauses in immediately adjacent position to their resumptive element, suggesting that these form a constituent together. This is visible from the fact that these can be coordinated as well:

(55) Rahul a:jkal [jo kita:b Saira-ne likh-i: vo] Rahul nowadays REL book Saira-ERG make-pfv DEM aur [jo cartoon Shyam-ne bana:-ya: vo] paŗh raha: hai and REL cartoon Shyam-ERG make-pfv DEM read prog be.prs 'Nowadays, Rahul is reading the book that Saira wrote and the cartoon that Shyam made.' 
Evidence for the overt syntactic movement of the relative clause from the low position in the demonstrative complex up to IP-initial position is provided by the usual movement diagnostics: island sensitivity and reconstruction effects.

The analysis of the Hungarian facts, as we have seen above in section 3 and the present section, is slightly different from Hindi correlativization. First of all, local adjunction of the correlative clause to the demonstrative correlate is immediately ruled out as an option, as the equivalents of (54) and (55) are starkly ungrammatical:

$$
\begin{aligned}
& \text { (56)*[ } \begin{array}{l}
\text { Aki jelentezett az órára az } \\
\text { REL-who signed the class-FOR that }
\end{array} \\
& {\left[\begin{array}{l}
\text { amelyik könyvet elkérte azt }] \text { el is olvasta. } \\
\text { REL-which book-ACC asked that-ACC PV also read }
\end{array}\right.}
\end{aligned}
$$

'The boy who signed up for the class read the book that he asked for.'

$$
\begin{aligned}
& \text { (57)* }\left[\begin{array}{l}
\text { Amit Mari fözött azt }] \\
\text { REL-what-ACC Mari cooked that-ACC }
\end{array}\right. \\
& \text { és [amitr Panna vett azt] megettem. } \\
& \text { and REL-what-ACC Panna bought that-ACC ate-1SG } \\
& \text { 'I ate what Mari cooked and what Panna bought.' }
\end{aligned}
$$

These examples show that the correlative clause cannot be generated as one constituent together with the demonstrative item in Hungarian. This makes it very unlikely that the correlative clause originates from a position adjoined to the demonstrative. As section 3.4 has shown, reconstruction facts unambiguously argue against such a stance, too: the correlative clause does not reconstruct. In the case of (17), the relative clause is not interpreted in the object position:

(17) $[$ RC Akit szeret Mari $\left.\mathrm{i}_{\mathrm{i}}\right]$, azt meghívta pro $_{\mathrm{i}}$ a buliba. REL-who-ACC loves Mari that-ACC invited the party-TO 'Who(ever) Mari loves, she invited to the party.'

Like the Binding Principle $\mathrm{C}$ effects, pronominal binding indicates lack of reconstruction, too. In the following examples, the relative pronominal cannot be bound by the matrix clause subject:

(58) [ Amelyik lány megcsókolta], abban minden fiú megbízik. REL-which girl kissed pro $_{\text {obj,i }}$ that-IN every boy trusts $^{2}$

'*Every boy trusts the girl who kissed him.'

Multiple relatives give the same results. They cannot overtly occur in any position next to their demonstrative associate (see example 21 above), and they do not show reconstruction, either: 
(59)

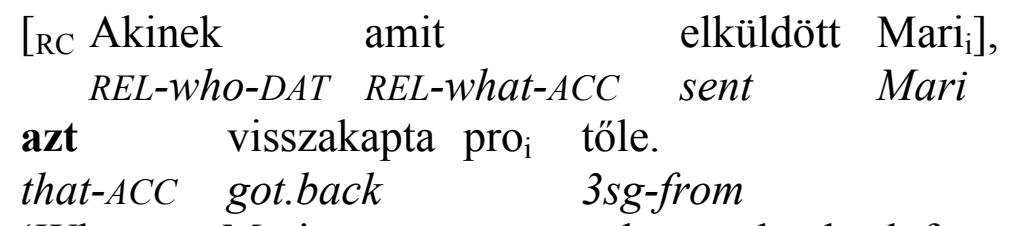

'Whatever Mari sent to anyone, she got that back from that person.'

These facts all militate against taking the correlative clause to originate in a position adjoined to the demonstrative. Not only are they not adjoined to each other in the base, they need not even originate in the same clause. In case the relative clause and the resumptive pronominal surface in two different clauses (which is a generally marked construction), it can be shown that the relative does not reconstruct back into either clause. To the extent that examples of this type are grammatical, they allow for coindexing between an R-expression in the relative clause and the subject of the intermediate one:

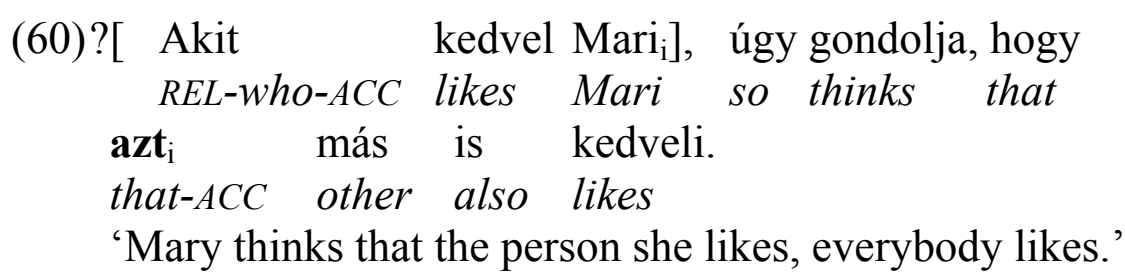

The sentences in (17) as well as (58)-(60) indicate that the correlative clause originates in the left periphery at the position where it surfaces. Its relation to the demonstrative resumptive in the main clause is that of variable-binding. ${ }^{9}$

The crucial difference between Hungarian and Hindi then is that in Hungarian both single and multiple relatives are base-generated on the left, while in Hindi only multiple ones are. In Hindi, merging the correlative with the demonstrative that it modifies is available as an option (and therefore forced by economy; see Bhatt 2003) but in Hungarian it is not. As Izvorski (1996) shows, Slavic languages, where local merge is not available either,

\footnotetext{
${ }^{9}$ The variable-binding approach to correlatives makes the prediction that one can find no locality effects between the correlative clause and the demonstrative correlate (as variable binding is possible long distance and across islands, as well). While judgements are shaky, $50 \%$ of my informants accepted sentences like (i) and (ii) where relative clause and demonstrative spread across an island:
}

(i) \%[ Amennyit János keres], azt a pletykát hallottam, REL-how.much-ACC John earns that-ACC the rumour-ACC heard-1sg hogy annyit Mari is keres. that that.much-ACC Mari also earns 'I heard the rumour that Mari earns (at least) as much as John does.'

(ii) $\%$ A Akit Anna a férjeként emleget], az a hír járja, REL-who-ACC Anna the husband-AS mentions that the news goes hogy az Angliában él. that that England-IN lives 'Rumour has it that the person Anna refers to as her husband lives in England.' 
pattern with Hungarian in this respect. This constitutes an important typological difference between Hindi-type and Hungarian/Slavic-type languages.

A final point concerns the position of the correlative clause in the left periphery in Hungarian. From the fact that the finite complementizer can, but topics cannot, precede correlatives in Hungarian, as was demonstrated in section 4 above, we have concluded that the position for correlatives is structurally higher than that of ordinary topics (TopP) and lower than that of the finite complementizer $\left(\mathrm{C}^{0}\right)$ :

$$
\text { (61) }\left[\mathrm { CP } [ \mathrm { RC } \text { REL-wh } ] _ { \mathrm { i } } \quad \left[\mathrm{Topp}^{*} \quad\left[\begin{array}{lll}
\ldots & \mathrm{DEM}_{\mathrm{I}} \ldots
\end{array}\right]\right.\right.
$$

It could therefore be assumed that the correlatives are adjoined to the highest topic projection in the clause, TopP if there is one in the sentence, and if there is none, to the highest projection distinct from $\mathrm{C}$.

Note that (61) as it stands does not provide any explanation for the fact that there can be at most one correlative clause in a Hungarian sentence. Adjunction in general is not restricted to one adjoinee. However, Hungarian is not alone in restricting the number of correlatives to one: to my knowledge, all languages with correlatives restrict the number of possible correlatives to one per clause. This is a yet ill-understood property of correlativization that to my knowledge has not been addressed by scholars. ${ }^{10}$

While clearly more research is required to clarify this point, the rest of this section has hopefully succeeded in showing many other things. Among these, first and foremost, is that Hungarian LPRCs are correlatives. It was shown that these clauses are base-generated free relatives which are linked to a

${ }^{10}$ In the recent literature on correlatives one can find a coordination-based account for correlativization, as well by Rebuschi (2003). Using comparative evidence from many languages, Rebuschi shows that and-coordination is often an ingredient of correlative structures. The following provides an example from Basque, where one optionally finds eta 'and' between the correlative and the main clause:

(i) Zure ontasun non, eta zure bihotza han. your treasure where and your heart there

'Where your treasure is, there's your heart.'

Based on this example, Rebuschi proposes the coordinate structure in (ii) (marked \&P here):

(ii) $\left[\& \mathrm{P}\left[{ }_{R C}\right] \quad\left[\& \&^{\prime} \& \quad[\right.\right.$ main clause $\cdots$... $\left.]\right]$

While attractive, this configuration cannot not account for the uniqueness of the correlative clause, either, as \&Ps are quintessential iterable categories. Moreover, a structure like (ii) would predict that it is impossible to extract anything out of the main clause due to a run-ofthe-mill ATB-violation, contrary to fact:

(iii) ? Miröl $l_{\mathrm{i}}$ szeretnéd, ha [aki jelentkezik] az írna $t_{\mathrm{i}}$ ? what-ABOUT like-cond.2sg if REL-who signs that writes 'What would you like people who sign up to write about?' 
correlative phrase in the main clause. They are true 'hanging' elements in that they are extrasentential and cannot be transformationally linked to any internal constituent of the clause. This result brings Hungarian closer to typologically distinct correlativization languages and provides the research field of correlativization with novel empirical and theoretical input.

\section{Conclusion}

This paper has taken a detailed look at the distribution of LPRCs in Hungarian. It has shown that these relative clauses are crucially distinct from relatives that are embedded under a nominal: LPRCs are base-generated free relative clauses. To give a syntactic account of their left-peripheral placement, LPRCs were compared to left-dislocated element in Hungarian, and it was shown that although there are some similarities between the two, there are crucial differences that militate against a parallel treatment. Hungarian LPRCs were then compared to Hindi-type correlative clauses and it was found that the properties of the two dovetail neatly: LPRCs can be successfully analyzed as correlative clauses.

\section{References}

Anagnostopoulou et al.1997. Materials on Left Dislocation. John Benjamins, Amsterdam.

Bhatt, Rajesh. 2003. Locality in Correlatives. Natural Language and Linguistic Theory 21: 485-541.

Citko, Barbara. 2004. On Headed, Headless and Light-headed Relatives. Natural Language and Linguistic Theory 22: 95-126.

Dasgupta, Probal. 1980. Questions and Relative and Complement Clauses in a Bangla Grammar. Ph.D. diss., New York University, NY.

Dayal, Vaneeta. 1996. Locality in Wh-quantification: Questions and Relative Clauses in Hindi. Studies in Linguistics and Philosophy 62. Kluwer, Dordrecht.

Gécseg, Zsuzsanna. 2001. A kontrasztív topik szintaxisáról és szemantikájáról. Magyar Nyelv XCVII/4.

Grohmann, Kleanthes. 2000. Copy Left Dislocation. In R. Billerey \& B. D. Lillehaugen, eds., WCCFL 19 Proceedings. Cascadilla Press, Somerville, MA, pp. 139-152.

É. Kiss, Katalin. 1987. Configurationality in Hungarian. Akadémiai Kiadó, Budapest.

Fox, Danny. 2000. Reconstruction, Binding Theory and the Interpretation of Chains. Linguistic Inquiry 30: 157-196.

Izvorski, Roumyana. 1996. The Syntax and Semantics of Correlative Proforms. In K. Kusumoto, ed., Procedings of NELS 26. GLSA Amherst, MA, pp. 133-147.

Jacobson, Pauline. 1995. On the Quantificational Force of English Free Relatives. In E. Bach et al., eds, Quantification in Natural Languages. Kluwer, Dordrecht.

Kayne, Richard. 1994. The Antisymmetry of Syntax. MIT Press, Cambridge, MA.

Kenesei, Istvàn. 1992. Az alárendelés. In F. Kiefer \& K. É. Kiss, eds., Strukturális magyar nyelvtan. I. Akadémiai Kiadó, Budapest.

Kenesei, Istvàn. 1994. Subordination. Syntax and Semantics 27. 
Lehmann, Christian. 1984. Der Relativsatz. Gunter Narr Verlag, Tübingen.

Lipták, Anikó. 2000. Multiple Relatives as Relatives of Hungarian. Approaches to Hungarian 8. Jate Press, Szeged.

Lipták, Anikó. 2001. On the Syntax of Wh-items in Hungarian. LOT Dissertation Series.

Prince, Ellen. 1998. On the Limits of Syntax, with Reference to Left Dislocation and Topicalization. Syntax and Semantics 29.

Rebuschi, Georges. 2003. Towards a Theoretical Treatment of Left Hanging Subordinate Clauses. In J. M. Makatzaga \& B. Oyharçabal, eds, Euskal gramatikari eta literaturari ikerketak XXI. mendearen atarian. Bilbao, Euskaltzaindia, Iker 14-1.

Sahoo, K. \& L. Hellan. 1998. Multiple Correlativization in Oriya. Paper presented at Console 8. University of Bergen, Norway.

Smits, R. 1988. The Relative and Cleft Constructions of the Germanic and Romance Languages. Ph.D. diss., Katholieke Universiteit Brabant. Foris, Dordrecht.

Srivastav, Vaneeta. 1991. The Syntax and Semantics of Correlatives. Natural Language and Linguistic Theory 9: 637-686.

Vergnaud, J-R. 1974. French Relative Clauses. Ph.D. diss., MIT, Cambridge, MA.

Wali, Kashi. \& Omkar N. Koul. 1997. Kashmiri: A Cognitive-Descriptive Grammar. Descriptive Grammars. Routledge, London. 